\title{
COMPARISON OF GROCERY SHOPPING BEHAVIOUR OF SLOVAK RESIDENTS ON THE SLOVAK-AUSTRIAN BORDER: AN EMPIRICAL STUDY - HAINBURG AN DER DONAU
}

\section{Pavol Kita ${ }^{1}$, František Križan², Kristína Bilková3, Milan Zeman', Tomáš Siviček ${ }^{5}$}

1 University of Economics in Bratislava, Faculty of Trade, Department of Marketing, Slovakia, ORCID: 0000-00015870-9328, pavol.kita@euba.sk;

2 Comenius University in Bratislava, Faculty of Natural Sciences, Department of Regional Geography, Protection and Planning of the Landscape, Slovakia, ORCID: 0000-0003-3410-2630, frantisek.krizan@uniba.sk;

3 Slovak Academy of Sciences, Institute of Geography, Slovakia, ORCID: 0000-0002-8912-4450, kristina.bilkova@ savba.sk;

4 Slovak Academy of Sciences, Institute for Sociology, Slovakia, ORCID: 0000-0002-3237-6390, milan.zeman@ savba.sk;

5 J. E. Purkyne University in Usti nad Labem, Faculty of Social and Economic Studies, Department of Economics and Management, Czech Republic, ORCID: 0000-0003-2365-724, tomas.sivicek@ujep.cz.

\begin{abstract}
Food is a part of human life, forming its existential and cultural basis. It also has become the basis of trade and a measure of the level of one or another culture, the engine of economic development. All these themes resonate more and more in debates in Slovakia as well. There are several reasons why. Slovaks still pay relatively more for food in comparison to neighbouring Austrians, who benefit from a rich offer of food at an affordable price. This might be related to an organized agricultural landscape, which is the product of economically prosperous food production. Bratislava residents' dissatisfaction with shopping experiences and products on offer in the current retail network in Bratislava forces them to travel to shop in the town of Hainburg an der Donau. The article states the types of Slovak consumers and their identities. An empirical study was conducted on a sample of 909 Slovak consumers shopping in Austrian grocery stores located in Hainburg an der Donau on the Slovak-Austrian border. The respondents rated their shopping experience and products on offer in the town. The study compares Slovak and Austrian stores based on the consumers' reasoning behind purchasing food in Austria and consumer satisfaction with the stores in both countries. Multidimensional scaling was used to present the results of the study. The results of the study represent a comparison of shopping behaviour of Slovak residents when considering shopping in Austria. Constructed perception maps identify the main types of consumers indicating the largest discrepancy in purchasing groceries in Austrian and Slovak stores.
\end{abstract}

Keywords: Consumer behaviour, typology of consumers, cross-border shopping, Hainburg an der Donau, Bratislava, multidimensional scaling, retail, Slovakia, Austria, grocery.

JEL Classification: D12, M31, L81.

APA Style Citation: Kita, P., Križan, F., Bilková, K., Zeman, M., \& Siviček, T. (2020). Comparison of Grocery Shopping Behaviour of Slovak Residents on the Slovak-Austrian Border: an Empirical Study - Hainburg an der Donau. E\&M Economics and Management, 23(1), 215-230. https://doi.org/10.15240/tul/001/2020-1-015 


\section{Introduction}

A myriad of factors influences every area of human activity. Recognition of these factors enables a responsible approach in environmental organization, modification and subsequent adaptation. This is also true for a consumer which feels a lack of the availability of specific merchandise. If this need is not satisfied, the consumer does one of two things, either he searches for a product which can satisfy the need or tries to suppress the need (Kita, 2016). In this respect, cross-border shopping offers new sources of opportunities to satisfy needs, find more suitable financial conditions or change expectations about a product. This means that these consumers may have a tendency to spend more in search for the highest quality among local or branded products. In the context of travelling abroad, Choi et al. (2016) claim that shopping has become a determining factor affecting destination choice. Travelling to shop abroad represents a specific aspect of shopping (Bygvrå, 2019; Spierings \& van der Velde, 2008; Timothy \& Butler, 1995; Powęska, 2008) when other regions attract new consumers (Balogh \& Pete, 2018; Doong, Wang, \& Law, 2012).

Consequently, in a market scenario the retailer in Bratislava is faced with a situation where generating a profit does not suffice anymore. They are forced to differentiate not only from local competitors but also foreign ones (Krásný, 1992; Drtina, 1995). Recognizing what kind of consumer visits the retail unit helps the effort to tailor the offering to better suit consumer needs and demands, thus classifying them into different types. Hence, the recognition of different types of consumer personalities enables appropriating adequate behavioural models for sales personnel (Binsztok, 2011; Hogan, 2010).

In recent studies, many authors have explored various topics in cross-border shopping, including market differences (BarKolelis \& Dopierala, 2014; Di Matteo \& Di Matteo, 1996), consumer satisfaction (e.g. Albayarak et al., 2016; Murphy et al., 2011; Szytniewski et al., 2017; Sharma et al., 2015), and behavioural intentions (Choi et al., 2018, 2016; Régi et al., 2015; Zinser \& Brunswick, 2014; Juan et al., 2013). Alongside this deliberate behaviour, psychological factors of consumer behaviour are connected to the perception of the environment upon which the unique way of thinking is explained, i.e. changes in opinion about domestic shopping conditions opposed to those abroad. The consumer uses one or more senses to interpret stimulus and directly respond to the retailers offering through his behaviour. Each individual/consumer also has their own individual traits (stability - instability, contemplativeness - impulsiveness, activeness - passiveness, calmness - nervousness, etc.) which largely influence their shopping behaviour (cf. Spilková, 2018).

The paper's authors acknowledge the fact that the key factor in generating a profit for grocery retailers is the customer. The aim of this paper is to compare, using Hainburg an der Donau as an example, specific segments of Slovak consumers' shopping in domestic stores and abroad. Based on the consumer identities, Slovak retailers will be able to anticipate shopping decisions and improve the perception of grocery offerings in their own stores. The intention of the authors is to answer the following research questions: RQ1: Who are the customers shopping in Austria - in the shopping-centre Galeria Danubia in Hainburg an der Donau? What type of customers are distinctive to cross-border shopping in Austria? RQ2: Where do the Slovak consumers shopping in the shopping-centre Galleria Danubia come from? Where is the trade area of the Austrian shopping-centre located in the Slovak territory? RQ3: Which factors influence the decision of customers to shop in Austria (Hainburg an der Donau)?

\section{Literature Review}

Suppliers and sales techniques must adapt to different consumer behaviours. Two factors influence consumer behaviour:

- Self-confidence, i.e. the scale of which the individual has control over situations, thoughts, emotions, (Pilarska, 2016) and actions of others;

- Mood, i.e. level of emotional expression and relational development with others (Thomson \& Crocker, 2013).

This kind of behavioural classification of consumers enables their allotment into several types depending on their traits suggested by various authors. Therefore, Tab. 1 demonstrates only the typologies relevant to our research.

There are many types of consumer identities (Forehand et al., 2012), it should be noted that a single identity term can bridge 


\section{Tab. 1: Overview of consumer typologies}

\begin{tabular}{l|l|l}
\multicolumn{1}{c|}{ Literature } & \multicolumn{1}{|c}{ Criteria of identification } & \multicolumn{1}{c}{ Identification of shopper types } \\
\hline Stone (1954) & $\begin{array}{l}\text { Demographic, psychographic, } \\
\text { lifestyle, choice }\end{array}$ & $\begin{array}{l}\text { Economic shoppers, personalizing } \\
\text { shoppers, ethical shoppers, apathetic } \\
\text { shoppers }\end{array}$ \\
\hline Lumpkin (1984) & Age & $\begin{array}{l}\text { Active apparel shoppers, the uninvolved } \\
\text { (apathetic) shoppers, economic shoppers }\end{array}$ \\
\hline $\begin{array}{l}\text { Bellenger et al. } \\
\text { (1977) }\end{array}$ & $\begin{array}{l}\text { Importance of certain patronage } \\
\text { motivations of shopping-centre } \\
\text { customers }\end{array}$ & $\begin{array}{l}\text { Recreational shoppers, economic/ } \\
\text { convenience shoppers }\end{array}$ \\
\hline $\begin{array}{l}\text { Boedeker \& } \\
\text { Marjanen (1993) }\end{array}$ & Choice, age & $\begin{array}{l}\text { Convenience seekers without cars, new } \\
\text { type shoppers, traditional shoppers, product } \\
\text { shoppers, individualistic quality seekers, } \\
\text { inactive shoppers }\end{array}$ \\
\hline $\begin{array}{l}\text { Gicquel \& Castéran } \\
\text { (2016) }\end{array}$ & $\begin{array}{l}\text { Usage and shopping throughout } \\
\text { the cycle }\end{array}$ & $\begin{array}{l}\text { Enthusiastic shoppers, apathetic shoppers, } \\
\text { pragmatic shoppers }\end{array}$ \\
\hline
\end{tabular}

various classifications leading to provide a more comprehensive typology of consumers. To appropriate names to consumer types, it is necessary to note that consumers are influenced by the retail environment's structure and by the consumer's own socio-economical and physical characteristics (Kohijoki \& Marjanen, 2013). In our case, consumer identity, comprehending, categorizing, and naming of consumer segments is based on free associations, which are spontaneously expressed. Spontaneous links to personal stories in the store reflect a product preference that will remain consistent over time (Ardelet et al., 2015). Indeed, repeated usage of a product at home should not modify the preferences of consumers engaging in self-referencing narratives because this preference relies more on symbolic dimensions and benefits rather than rational evaluations of product's attributes.

The respondent typologies in this paper are suggested with the following characteristics: price oriented, picky, loyal, recreational, "fridge-type", pragmatic, apathetic to shopping, and uncategorized. From a psychological perspective, the identity of an individual represents the experience of satisfaction. It is defined as a subjective experience of existence (own authenticity, uniqueness), whether as an individual or member of human societies. Identity is created, preserved and persists mainly due to social interactions. (Akerlof \& Kranton, 2000). This means that choices of an individual define proper lifestyle and consumption habits, even if such identification is never expressed publicly or consciously perceived (Bock \& Uncles, 2002; Mark, Niraj, \& Dawar, 2012). The creation of an individual's identity is a long-term and difficult process of constant comparison and correction diminishing the differences between the individual's proper expectations and his wished expectations. Thus, we can analyse his shopping behaviour.

\section{Research Design and Methodology}

The primary method was a standardized questionnaire used to obtain responses (cf. Bygvrå, 1998; Civáň \& Krogmann, 2012; Križan et al., 2017). A total of 909 respondents took part in the survey, on the premises of the shopping centre Galleria Danubia in Hainburg an der Donau, between March and May (2015). The questionnaire consisted of 13 questions divided into 4 parts. The questions concentrated on:

- basic information about the respondent;

- commuting from the respondent place of residence to Hainburg an der Donau (3 questions);

- shopping in Austria and Slovakia (7 questions);

- respondent shopping behaviour (3 questions).

The questionnaire contained closed and open questions and there was the Likert Scale used for a group of questions. The interviews were conducted by instructed questioners by causal selection of respondents. 
Tab. 2: Sample of respondent distribution per gender $(n=909)$

\begin{tabular}{l|l|c|c} 
& & Bratislava & Other \\
\hline Sex & Male & $58.8 \%$ & $41.2 \%$ \\
\hline & Female & $62.0 \%$ & $38.0 \%$ \\
\hline Total & & $60.6 \%$ & $39.4 \%$ \\
\hline
\end{tabular}

Source: own

The sample consisted of mainly women $(60.6 \%)$. Compared to the whole sample these were mainly women from Bratislava (62\%) travelling to shop in Austria (Tab. 2). From a socio-demographic perspective, $60.6 \%$ of respondents came from Bratislava. The other two-fifths (39.4\%) stated other townships. In the case of respondents coming from Bratislava, there was a statistically significant portion of respondents living in households with fewer people, i.e. 1-member households (77.6\%) and two-member households (68.5\%). Equally significant was a lower portion of respondents living in four-member households (54.3\%) and households of five or more members $(41.0 \%)$.
From the aspect of education, respondents with secondary-school education ( $D$ - with GSCE equal to "Maturita" or high-school diploma) made up the highest proportion $(46.6 \%)$, followed by those with university education $(44 \%)$. More than three quarters $(76.6 \%)$ of respondents were 18-44-yearsold, and more than two-thirds $(67.7 \%)$ were employed (See Tab. 3). For statistical testing, we used the sign scheme, which is based on adjusted residuals in two-dimensional classification of signs and expresses statistical significance of difference between variables. Tab. 2 states the basic characteristics of the respondents. Obtained primary data of the

\section{Tab. 3: Basic sample characteristics}

\begin{tabular}{c|c|c|c|c|c|c|c|c|c|c} 
& \multicolumn{5}{|c|}{ Education } & \multicolumn{5}{c}{ Employment } \\
\hline Category & A & B & C & D & E & a & b & c & d & e \\
\hline$\%$ & 0.1 & 0.9 & 8.5 & 46.6 & 44.0 & 3.4 & 67.7 & 6.1 & 5.3 & 17.5 \\
\hline
\end{tabular}

Source: own

Note: A - without formal education, B - elementary education, C - secondary-school education without GSCE, D - secondary-school education, E - university education, a - unemployed, b - employed, c - maternity leave, $d$ - retiree, e-student.

\section{Fig. 1: Respondent income structure}

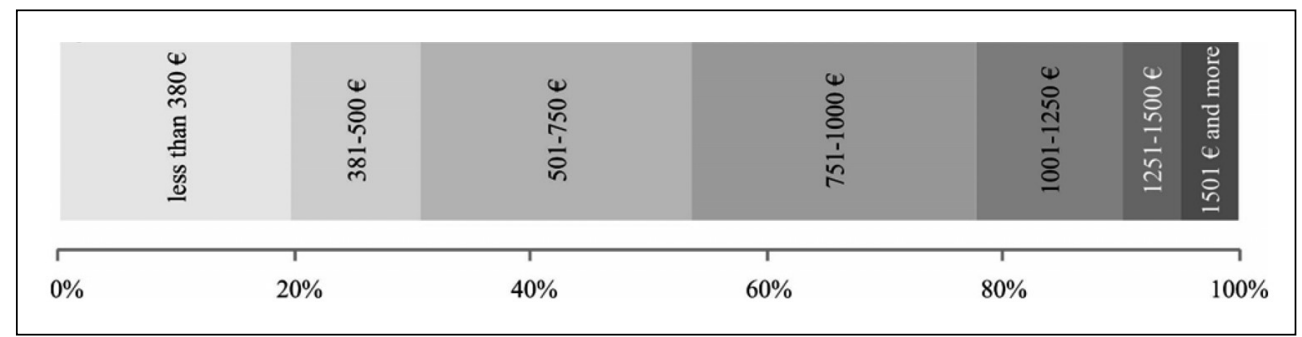


marketing survey was analysed in IBM SPSS enabling presentation in table or graphic form.

As for respondents living in townships other than Bratislava, there was a higher statistically significant portion of respondents living in households with more members, i.e. fourmember households (45.7\%) and households of five or more members $(59.0 \%)$. No other significant differences were found compared to the average (whole sample), in other sociodemographic categories. The largest portion of respondents $(24.1 \%)$ have an income equal to the average income in the Slovak economy. On the other hand, more than half have an income inferior to the average income (Fig. 1).

The second group of methods is based on delimitation of trade areas. For identification of trade areas, various methodological instruments might be used, while the delimitation based on perception and preferences belongs to standard instruments (Križan et al., 2017). The answers of respondents were geo-coded based on stated residence and subsequently they were processed by geographic information systems. The distance between the place of shopping and residence was measured by mutual (binary) level of accessibility (Maryáš et al., 2014). Based on this analysis, it is possible to single out the trade of the examined retail unit and the average transport distance of cross-border shopping.

Shopping in border areas affects the consumer's emotional state, stimulates cultural interactions between hosts and guests, and contributes to the local economy. Tourism researchers argue that shopping is the core contributor to visitor satisfaction and overall destination experience (Sirakaya-Turk et al., 2015). The third group of methods is based on Multidimensional scaling (MDS), a tool employed to find out the object positioning. MDS assumes that if two objects are relatively equal in basic attributes, they will be perceived as similar and vice versa (Jung \& Takane, 2015). Since MDS was based on psychology, the data used is based on direct similarity judgments. Respondent judgements are measured on Likert rating scales ranging from $1=$ the best to $5=$ the worst. The Likert scales enabled the respondent to express the appropriated level of importance or significance to corresponding traits of the retail unit. Furthermore, this enables the use of this qualitative data in quantitative analyses. Marcussen (2014) claims that MDS is not a probability model, and therefore it cannot be used to test hypotheses. If hypotheses need to be tested, other methods must be applied, either instead of or as a supplement to MDS. Perceptual mapping techniques are common in the diagnostic phase of a positioning studies (Mazanec, 1995). The general goal of MDS is to find relevant hidden dimensions which enable the marketing manager to explain similarities or discrepancies between studied objects (Kita \& Grossmanová, 2014). Thus, translating similarities or discrepancies into distance within a multidimensional space defined by the given number of dimensions enables the study of influences of the current order to explain original distances between objects, i.e. a perception map is limited to two or three dimensions and the created perceptual space "map" (Mazanec, 1995, 2009) may indicate which destinations are similar, and therefore competitors.

A matrix where data served as map coordinates for each type of consumer in SPSS. This was based on an aggregated evaluation of individual attributes of retail stores. Obviously, if objects of interest (such as destinations) are accessed on many different dimensions, compromises will ensure minimizing stress, if the positioning of destinations or other objects of interest are illustrated in a normal two-dimensional map. These dimensions do not have an explicit significance resulting directly from MDS. We can only assume that the significance of the dimension from a visual inspection of the relations and our knowledge about the objects displayed in the map (Meloun \& Militký, 2004).

Stress is the goodness-of-fit statistic that MDS tries to minimize. It consists of the square root of the normalized squared discrepancies between interpoint distances in the MDS plot and the smoothed distances predicted from the dissimilarities. Stress varies between 0 and 1 , with values near 0 indicating better fit (Wilkinson, 1998). Stress is indices that assess the mismatch of (admissibly transformed) proximities and corresponding distances. Stress is, in a way, like a correlation coefficient, except that it measures the badness-of-fit rather than the goodness-of-fit (Borg \& Groenen, 2005). Each of the four stress statistics measures the misfit of the data, while the dispersion accounted for and Tucker's coefficient of congruence measure the fit. We proceeded in accordance with Malhort (2008) and chose a direct method 
where respondents directly state subjective evaluation. Based on this, we can set distance among their criteria and name the axes of the perception map. The RSQ index meet the $60 \%$ criteria, therefore we did not reject this model.

\section{Results}

In the first part, the analysis is focused on identification of a typical consumer from Slovakia shopping in Austria. In general, there are two groups of consumers for discussion: (i) regularly, and (ii) irregularly shopping. Those, who shop regularly are 35-44-yearsold, with university education, employed and with above-average income. These consumers primarily use a car for shopping in Austria as a means of transport and they estimate that the time spent shopping in Austria is between 61 to 120 minutes per week. The reason for their shopping in Austria is habit and work and most often they buy driving fuel and food. The irregularly shopping consumers from Slovakia in Austria are young people of age of 18-24 years with secondary-school education (with GSCE/Maturita), students, and those with lower income (up to $500 €$ ). These consumers mainly use public/mass transport as a means of transportation. They estimate that the duration of their shopping in Austria is up to 30 minutes per week. Most frequently, they buy food and shoes in Austria.

The second part the analysis aims to delimit the trade area of SC Galleria Danubia. Almost two thirds of respondents $(60.6 \%)$ come to shop in Austria from Bratislava. However, up to $39.4 \%$ of consumers come from other regions (See Fig. 2). From them, the highest proportion is made up of buyers from cities: Trnava (4.6\%), Pezinok (3.4\%), Senec (3.4\%), Stupava $(1.6 \%)$ and Malacky (1.4\%). The Slovak residents from Hainburg account for $1.5 \%$ of respondents. Inquired consumers come from 107 municipalities, three of which were Austrian and one Hungarian. Only perceptions and preferences of customers living in Slovakia were analysed. The significant majority of buyers $(89.1 \%)$ live in cities. The average distance between location of residence and place of shopping in Austria is $51.8 \mathrm{~km}$, whereas $78 \%$ of consumers live up to $50 \mathrm{~km}$ from the shoppingcentre, and $88 \%$ of consumers live within the distance of $100 \mathrm{~km}$.

The third part of the analysis focused on assessing reasons of purchase abroad and on classification of customers. Besides basic respondent information, the following areas

\section{Fig. 2: Locations of residence of customers from Slovakia shopping} in the shopping-centre Galleria Danubia in Hainburg an der Donau in Austria

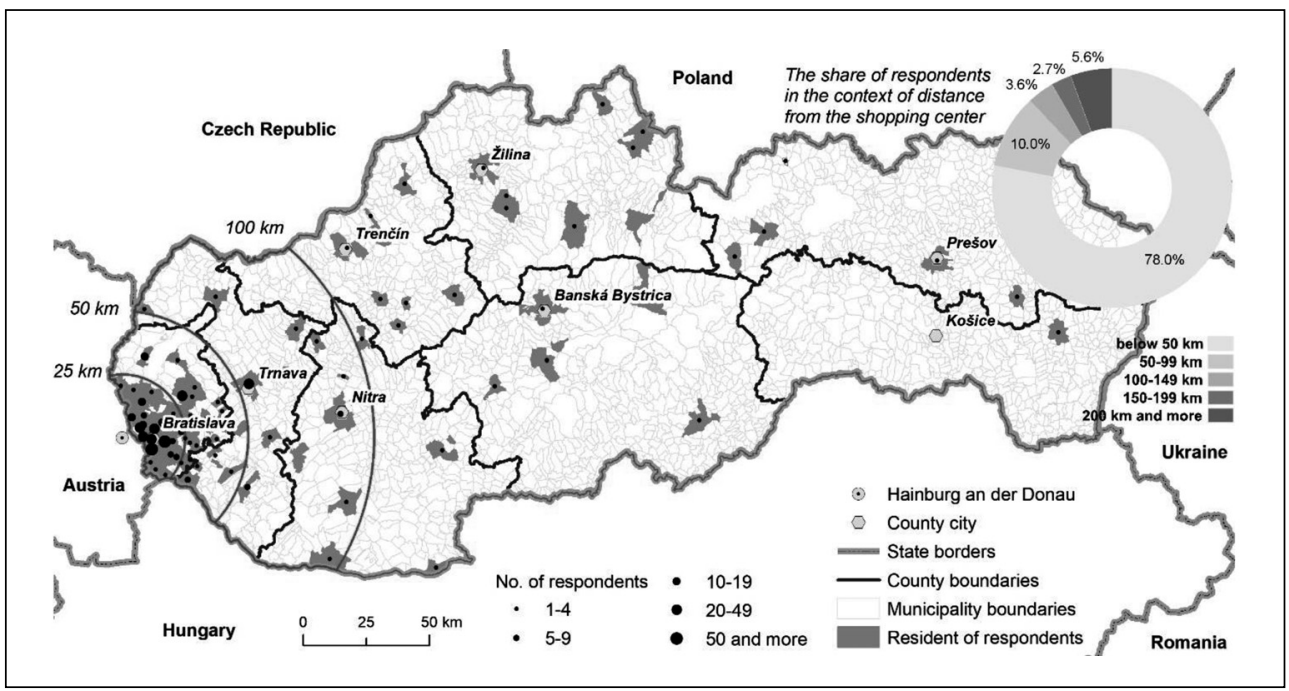




\section{Fig. 3: Reasoning behind shopping in Austria}

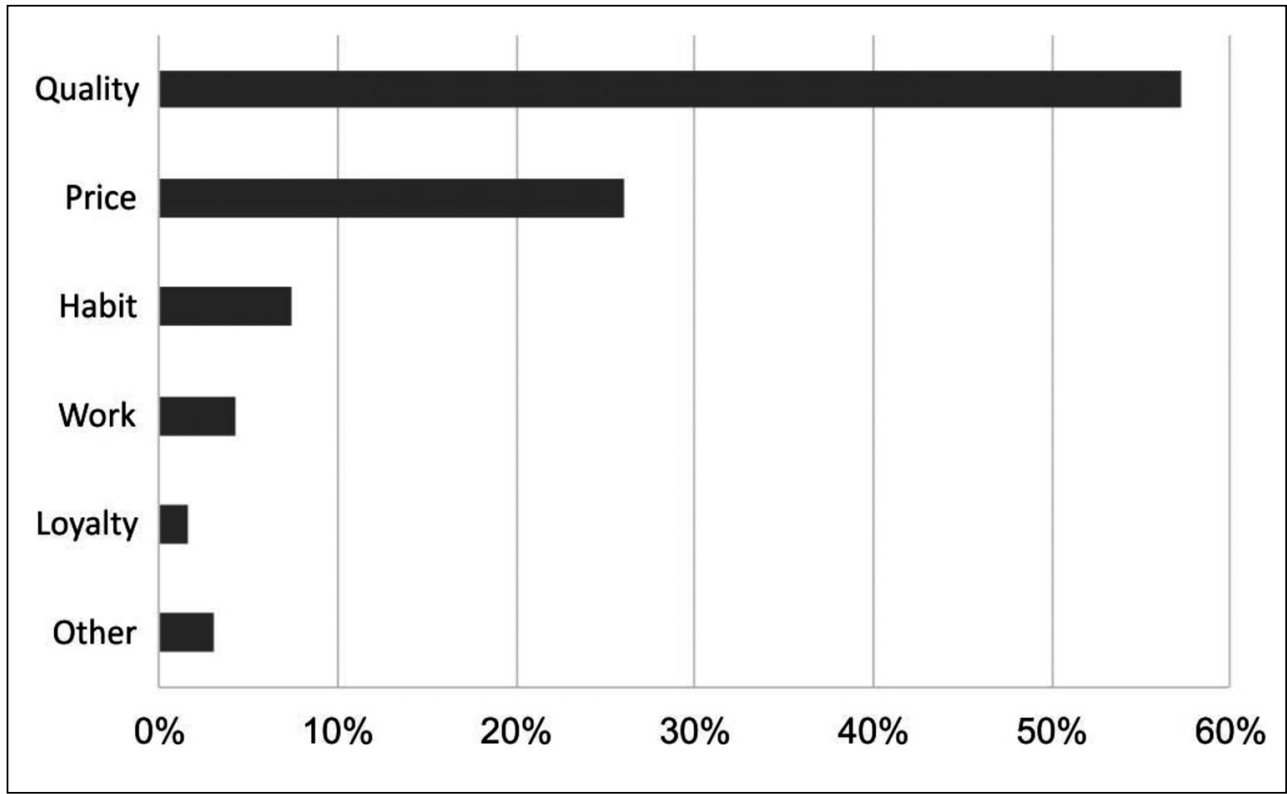

Source: own

were analysed to evaluate the retail offerings in Hainburg an der Donau, on the Slovak-Austrian border:

- reasoning behind shopping in Austria;

- satisfaction with shopping in Austria and in Slovakia.

Five reasons to shop in Austria were selected and asked in a semi-closed questions. The given options were believed to motive consumers to travel for grocery shopping. In relation to this, Mattioli and Anable (2015) describe travelling for grocery shopping as a derived demand. In this context, Fig. 3 demonstrates the two main reasons why people become attached to different locations and extend well beyond the location's physical characteristics, the types of products it sells and/or the level of service it provides (Johnstone \& Conroy, 2008).

More than half $(57.2 \%)$ responded that quality is their main reason to travel. The second reason motivating consumers is price $(26.0 \%)$. Quality and price represent $83.2 \%$. In relation to the entire sample $(57.2 \%)$, there were no significant findings that prove that quality is the main motive to shop in Austria in any sociodemographic category. A statistically significant lower portion of respondents for whom quality is the main reason to shop in Austria was found among respondents of 55 years or older $(42.9 \%)$ and retirees $(40.0 \%)$. Compared to the whole sample $(26.0 \%)$, respondents who claimed that price was the main reason for shopping in Austria, a statistically larger portion of respondents were among respondents with secondary-school education with graduation $(31.3 \%)$. Among the $7.3 \%$ of respondents claiming that habit is the main reason to shop in Austria, a very strong statistical significance was found among respondents older than 55 years $(15.5 \%)$, respondents with lower education without graduation $(17.3 \%)$. This could point to the existence of consumers which have been shopping in Austria persistently and almost do not shop in Slovak stores. This survey also indicates work as a situational factor ( $4.4 \%$ of respondents), i.e. they commute to Austria because of work. Other reasons were loyalty $(1.7 \%)$ and other reasons $(3.3 \%)$ which lead respondents to shop in Austria. 
The most frequent of which are: curiousness, place of residence, assortment, other kinds of merchandise, sales, brands, family visits, road trips, recreation, and vacation.

To compare satisfaction with shopping in Austria and Slovakia, respondents ranked the level of their degree/disagree on Likert scale. Attribute measurement of Austrian and Slovak stores was performed on four factors:

- Price (represents the financial layer of selling in the stores);

- Quality (represents the physical layer of sold product in stores);

- Choice of assortment (represents the level of services available in the stores);

- Total satisfaction (represents the psychological attribute of evaluating the level of presentation of stores).

The created perception map shows how the 8 types of consumers perceive the utility and advantages of shopping in SR (Slovak Republic) and AT (Austria); and integrate them into their decision-making. The corresponding consumer types have these traits (see Tab. 4):

1. The price-oriented consumer is female $(31.2 \%), 55$ years or older $(34.1 \%)$ with a lower education without graduation $(31.3 \%)$, retired $(32.6 \%)$ with an income up to $380 €(37.1 \%)$ living in households of 5 or more members $(39.8 \%)$.

2. The picky consumer is male $(21.3 \%)$; 55 years or older $(22.4 \%)$ with college or university education (20.9\%), mostly retired $(30.4 \%)$ with an income of $1,501 €$ and more $(31.7 \%)$; living in 2-member households $(23.0 \%)$.

3. The loyal consumer is male $(7.2 \%) ; 35-44$ years-old $(22.4 \%)$ with secondary school education $(6.1 \%)$ mainly unemployed $(10.0 \%)$ with an income ranging from 1,001 to $1,250 €(8.3 \%)$ living in 3-member households (23.0\%).

4. The recreational shopper is female $(9.3 \%)$, 18-24 years old $(12.6 \%)$ with secondaryschool education (10.4\%), mainly unemployed $(13.3 \%)$ with an income from $381-500 €(17.0 \%)$ living in households of 5 or more members $(12.0 \%)$.

5. The "fridge-type" shopper is male $(6.9 \%)$, 25-34 years-old (7.2\%) with a lower education without graduation (8.4\%), mainly on maternal leave $(13.2 \%)$ with an income of $751-1,000 €(7.8 \%)$ living in 4-member households (23.0\%).

6. The pragmatic consumer is female $(19.0 \%)$, 55 years or older $(18.8 \%)$ with college or university education (18.4\%), mostly unemployed $(20.0 \%)$ with an income of $1,001-1,250 €(25.0 \%)$ living if 3-member households (19.3\%).

7. The apathetic consumer is male $(5.2 \%)$, 25-34 years old $(5.4 \%)$ with college or university education $(4.3 \%)$, employed $(4.6 \%)$ with an income between $751-1,000 €$ $(5.4 \%)$ living in 2-member households $(6.2 \%)$.

8. The uncategorized consumer is male $(9.9 \%)$, between $35-44$ years old $(11.2 \%)$

\section{Tab. 4: Which of the consumer types describes you the best? (\%) - Part 1}

\begin{tabular}{|c|c|c|c|c|c|c|c|c|c|c|}
\hline \multicolumn{2}{|c|}{$\mathrm{n}=909$ respondents } & A & B & C & D & $E$ & $F$ & G & H & $\begin{array}{c}\text { no } \\
\text { answer }\end{array}$ \\
\hline \multicolumn{2}{|c|}{ ENTIRE SAMPLE } & 28.4 & 8.9 & 3.7 & 20.0 & 6.4 & 8.8 & 5.7 & 17.4 & 0.7 \\
\hline \multirow{2}{*}{ 嵒 } & Male & 24.8 & 8.4 & $5.2^{*}$ & 21.3 & 6.9 & 9.9 & 7.2 & 15.4 & 0.7 \\
\hline & Female & $31.2^{*}$ & 9.3 & 2.6 & 19.0 & 5.9 & 7.9 & 4.5 & 19.0 & 0.6 \\
\hline \multirow{6}{*}{ 岁 } & $18-24$ yrs & 31.7 & 12.6 & 2.6 & 21.3 & 5.7 & 5.2 & 4.8 & 14.3 & 1.7 \\
\hline & $25-34$ yrs & 24.8 & 8.3 & 5.4 & 19.1 & 7.2 & 9.0 & 6.8 & 19.1 & 0.4 \\
\hline & $35-44$ yrs & 28.2 & 6.9 & 2.1 & 19.7 & 5.9 & 11.2 & 8.0 & 1.6 & 0.5 \\
\hline & $45-54$ yrs & 27.3 & 9.1 & 5.0 & 19.8 & 6.6 & 10.7 & 3.3 & 18.2 & \\
\hline & 55 yrs and more & 34.1 & 4.7 & 3.5 & 22.4 & 7.1 & 7.1 & 2.4 & 18.8 & \\
\hline & No answer & 14.3 & 14.3 & & & & 42.9 & 14.3 & 14.3 & \\
\hline
\end{tabular}




\section{Tab. 4: Which of the consumer types describes you the best? (\%) - Part 2}

\begin{tabular}{|c|c|c|c|c|c|c|c|c|c|c|}
\hline \multicolumn{2}{|c|}{$n=909$ respondents } & A & B & C & D & E & $F$ & G & $\mathrm{H}$ & $\begin{array}{c}\text { no } \\
\text { answer }\end{array}$ \\
\hline \multirow{4}{*}{$\begin{array}{l}\text { 을 } \\
\text { 엉 } \\
\text { 물 }\end{array}$} & $\begin{array}{l}\text { Elementary and } \\
\text { secondary without } \\
\text { GSCE }\end{array}$ & 31.3 & 9.6 & 2.4 & 19.3 & 8.4 & 7.2 & 2.4 & 16.9 & 2.4 \\
\hline & Secondary & 30.1 & 10.4 & 3.5 & 19.5 & 7.1 & 6.6 & 6.1 & 16.2 & 0.5 \\
\hline & University & 26.2 & 7.1 & 4.3 & 20.9 & 5.0 & 11.6 & 6.0 & 18.4 & 0.5 \\
\hline & No answer & & 25.0 & & & 25.0 & & & 50.0 & \\
\hline \multirow{6}{*}{ 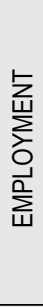 } & Unemployed & 30.0 & 13.3 & 3.3 & 6.7 & 10.0 & 6.7 & 10.0 & 20.0 & \\
\hline & Employed & 27.0 & 8.2 & 4.6 & 19.5 & 5.6 & 10.4 & 6.2 & 17.6 & 0.9 \\
\hline & Maternity leave & 28.3 & 9.4 & 1.9 & 15.1 & 13.2 & 7.5 & 5.4 & 18.9 & \\
\hline & Retiree & 32.6 & 4.3 & 2.2 & 30.4 & 8.7 & 4.3 & 2.2 & 15.2 & \\
\hline & Student & 30.3 & 13.2 & 2.6 & 21.7 & 6.6 & 5.9 & 4.6 & 15.1 & \\
\hline & No answer & 34.9 & 4.7 & & 25.6 & 2.3 & 4.7 & 4.7 & 20.9 & 2.3 \\
\hline \multirow{8}{*}{$\begin{array}{l}\text { 岁 } \\
\underline{O} \\
\underline{\mathrm{O}}\end{array}$} & Less than $380 €$ & 37.1 & 7.2 & 1.8 & 21.0 & 7.8 & 3.0 & 4.8 & 16.8 & 0.6 \\
\hline & $381-500 €$ & 28.7 & 17.0 & 5.3 & 16.0 & 5.3 & 9.6 & 4.3 & 12.8 & 1.1 \\
\hline & $501-750 €$ & 25.1 & 6.8 & 5.2 & 18.8 & 5.8 & 10.5 & 5.2 & 22.0 & 0.5 \\
\hline & $751-1,000 €$ & 25.9 & 9.3 & 5.4 & 20.5 & 7.8 & 11.2 & 5.9 & 13.7 & 0.5 \\
\hline & $1,001-1,250 €$ & 26.9 & 6.5 & 2.8 & 17.6 & 4.6 & 6.5 & 8.3 & 25.0 & 1.9 \\
\hline & $1,251-1,500 €$ & 16.3 & 7.0 & 2.3 & 27.9 & 4.7 & 14.0 & 7.0 & 20.9 & \\
\hline & $1,501 €$ and more & 24.4 & 4.9 & 2.4 & 31.7 & 7.3 & 14.6 & 4.9 & 9.8 & \\
\hline & No answer & 36.7 & 15.0 & & 16.7 & 5.0 & 6.7 & 6.7 & 13.3 & \\
\hline \multirow{6}{*}{$\begin{array}{l}\text { 岕 } \\
\text { D } \\
\text { 으 } \\
\text { 오 } \\
\text { ㅇ } \\
\text { 우 }\end{array}$} & 1 person & 32.8 & 9.8 & 4.9 & 21.3 & 4.9 & 6.6 & 3.3 & 16.4 & \\
\hline & 2 persons & 26.3 & 10.0 & 6.2 & 23.0 & 5.3 & 5.3 & 5.3 & 18.2 & 0.5 \\
\hline & 3 persons & 27.6 & 7.0 & 4.5 & 16.9 & 7.8 & 11.5 & 5.3 & 19.3 & \\
\hline & 4 persons & 26.8 & 7.7 & 2.3 & 19.5 & 8.8 & 9.6 & 8.0 & 15.7 & 1.5 \\
\hline & 5 and more persons & 39.8 & 12.0 & 0.9 & 20.4 & 1.9 & 7.4 & 3.7 & 13.0 & 0.9 \\
\hline & No answer & 11.1 & 14.8 & & 25.9 & & 14.8 & 3.7 & 29.6 & \\
\hline
\end{tabular}

Source: own

Note: A - Price oriented, B - Recreational, C - Apathetic, D - Picky, E - "Fridge-type", F - Uncategorized, G - Loyal, $\mathrm{H}$ - Pragmatic.

* In these categories, there were found statistically significant differences at the significance level $\alpha=0,05$. In other analysed socio-demographic categories, there were no statistically significant differences found in comparison with the average (whole sample). 
with college or university education (11.6\%), employed (10.4\%) with an income of $1,501 €$ and more (14.6\%) living in 3-member households (11.5\%).

The goal of this typology was to describe the differences in consumer satisfaction between shopping in Austria and Slovakia using a perception map. The perception map demonstrates a comparison which implies that consumers are generally more satisfied with shopping in Austria than in Slovakia (Fig. 4). The close distance between object clusters are relatively low according to the PROXSCAL procedure, i.e. each of the four stress statistics measures the misfit of the data, while the dispersion accounted for and Tucker's coefficient of congruence measure the fit. The stress measures were indicated: NRS (Normalized Row Stress) $=.01090$, Stress $\mathrm{I}=.10440$, Stress II $=.21809$, Stress $=.03211$, Dispersion Accounted for (DAF) $=.98910$ and Tucker's coefficient of congruence $=.99454$.

Consumers consider Slovak grocery stores as expensive because there is not much food of high quality on offer. On the contrary, Austrian shops offer a wide range of quality food at a lower or comparable price as in Slovakia.

Price was the first evaluated factor. Particularly, when price differences between neighbouring countries are high, consumers travel across the border mainly to shop (cf. Nagengast et al., 2015). Price plays a key role in the decision making of Slovak consumers, when choosing the location in their own environment. In general, Slovak consumers are more satisfied with the prices in Hainburg an der Donau (2.3 on average), opposed to the prices in Slovakia (average evaluation of 2.8). On the other hand, almost a tenth of Slovak consumers were critical about the prices in Hainburg an der Donau. In comparison, grocery prices are lower in Austria than in Slovakia. In general, the higher price level in Austria did not seem to form a significant barrier to shopping trips (Bygvrå, 2019).

The second evaluated factor was product quality. Here, the largest discrepancies were evident between the countries. Slovak consumers are largely more satisfied with product quality in Austria (1.9 on average) than in Slovakia (3.0 on average). While the average scores dominated in Slovakia $(47.5 \%)$, more than half of consumers evaluated the product quality in Hainburg an der Donau with high scores. The perception map shows the largest difference and distance between these points.

The evaluated factor was assortment. Even here we can observe a significant increase in respondent consumer satisfaction with shopping in Austria. This factor is in favour of the Austrian town, although Slovak retail has developed in recent years due to globalization trends typical for western European countries (Križan et al., 2016; Kunc \& Križan, 2018). While less than half of consumer in Slovakia are satisfied with the assortment (better evaluation than 3), more than two thirds of consumers are more satisfied with the assortment of goods in Hainburg an der Donau.

The average total consumer satisfaction with shopping is in Hainburg an der Donau. On the one hand, Slovak consumers evaluate retail stores in Slovakia in most cases with an average score and positive scores (1 or 2) in the Austrian town. On the other hand, the lowest scores are seldom for retail stores in Slovakia, compared to Hainburg an der Donau where it is more prevalent.

In the context of cross-border shopping, there are observable changes in Fig. $5 \mathrm{~A}$ and $B$ in evaluation of shopping in Austrian and Slovak stores. Map A demonstrates evaluation of shopping in Slovakia. The stress measures for map A were indicated: NRS $=.00067$, Stress $\mathrm{I}=.02582$, Stress $\mathrm{II}=.04879$, Stress $=.00171$, DAF $=.99933$ and Tucker's coefficient of congruence $=.99871$. Using a hierarchical method based on the value from decomposing the Normalized Raw stress the following clusters were identified:

1. cluster - C_3, C_4, C_5 and C_6;

2. cluster - C_2, C_7 and C_8;

3. cluster-C_1.

Fig. $5 \mathrm{~B}$ demonstrates evaluations of shopping in AT. The stress measures for a fig. 5 B were indicated: NRS $=.0258$, Stress $\mathrm{I}=.05079$, Stress $\mathrm{II}=.09959$, Stress $=.0780$, DAF $=.99871$ and Tucker's coefficient of congruence $=.99967$. We proceed to identify cluster in the same manner as with Fig. $5 \mathrm{~A}$. the following clusters were identified (Fig. $5 \mathrm{~B}$ ):

1. cluster - C_5 and C_6;

2. cluster $-C_{-}-1, C \_2, \bar{C} \_4$ and C_7 ;

3. cluster $-\mathrm{C}_{-} 3$ and $\mathrm{C} \_\overline{8}$.

According to Bajs (2011), shopping attributes may be identified differently, depending on the destination-specific factors and measurement tools. Perceived value is mostly defined as the 


\section{Fig. 4: Comparing the evaluation of shopping in Austria and Slovakia}

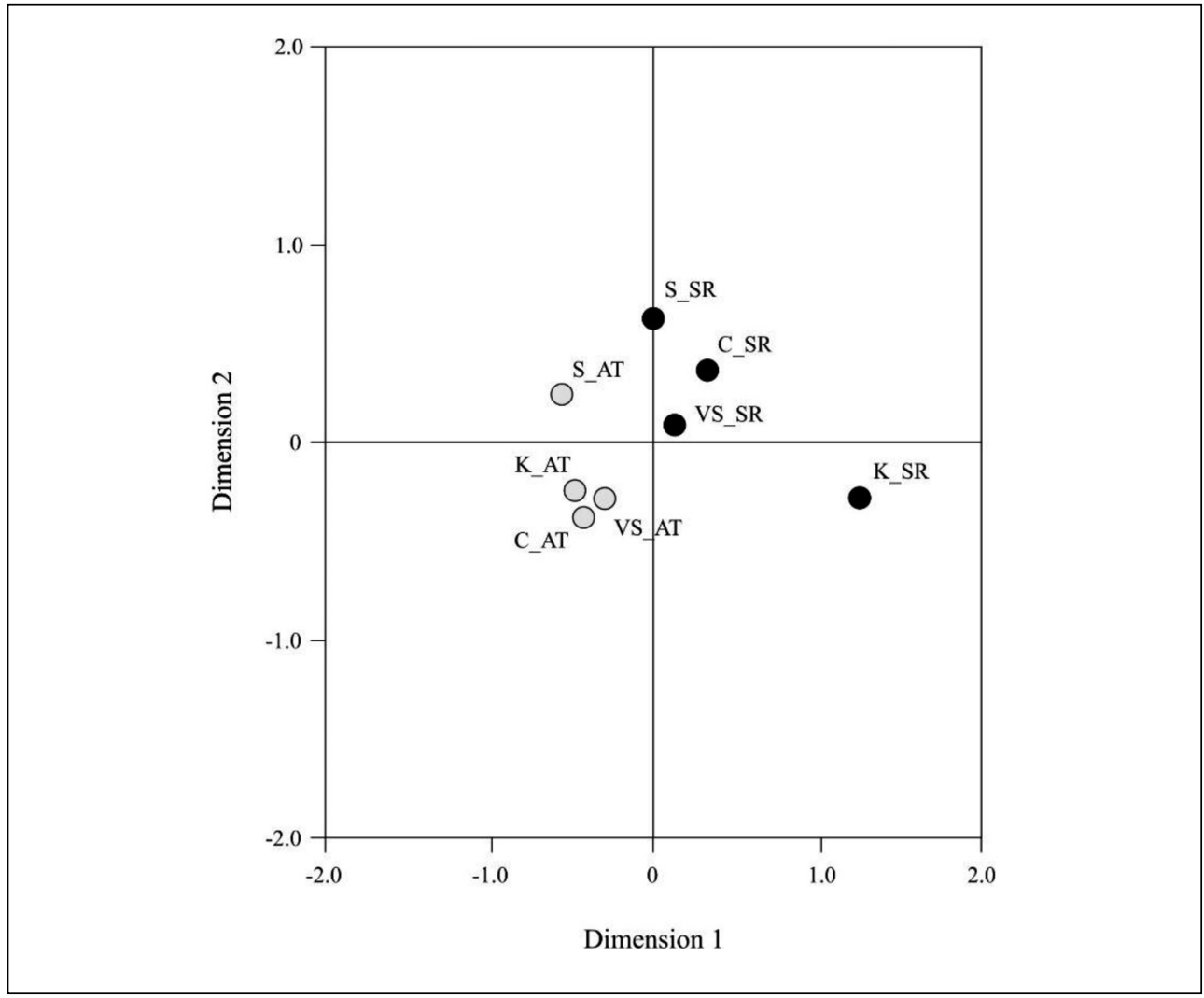

Source: own

Note: Dimension 1 - low price - high price; Dimension 2 - narrow range of quality food - wide range of quality food. C_SR - price in Slovakia, C_AT - price in Austria, K SR - quality in Slovakia, K AT - quality in Austria, VS SR assortment choice in Slovakia, VS_AT - assortment choice in Austria, S_SR - total satisfaction in Slovakia, S_AT - total satisfaction in Austria.

consumers' overall assessment of the utility of a product or a service based on what is received and what is given (Zeithaml, 1988). Zeithaml (1988) suggested that value perception "involves not only price variations but also other psychological factors" (Jamal et al., 2011). MDS thus typically added to it, as an implicit purpose, the search for "underlying dimensions" that would explain observed similarities or dissimilarities (Borg \& Groenen, 2005). On the whole, the map indicates moderate satisfaction levels since most objects are concentrated at its centre, i.e. near the cross. This indicates that product prices do not have to be the main criteria in shopping decisions. While elaborating on the behaviour of Slovak consumer behaviour in Slovakia we take into account the fact that price and quality are contradictory to each other. Therefore, we can consider price as a factor of sales dependent on the level of the stores offering which is closely related to the quality of shopping. In relation to the created maps, we can point out the fact that some types of consumers have very similar shopping behaviour in both countries (Fig. 5). This shows that some types of consumers transfer their behavioural model and do not change. The apathic (C_7), the recreational (C_4), and 


\section{Fig. 5: Changes in consumer behavioural models under evaluation of shopping in Austrian and Slovak stores}

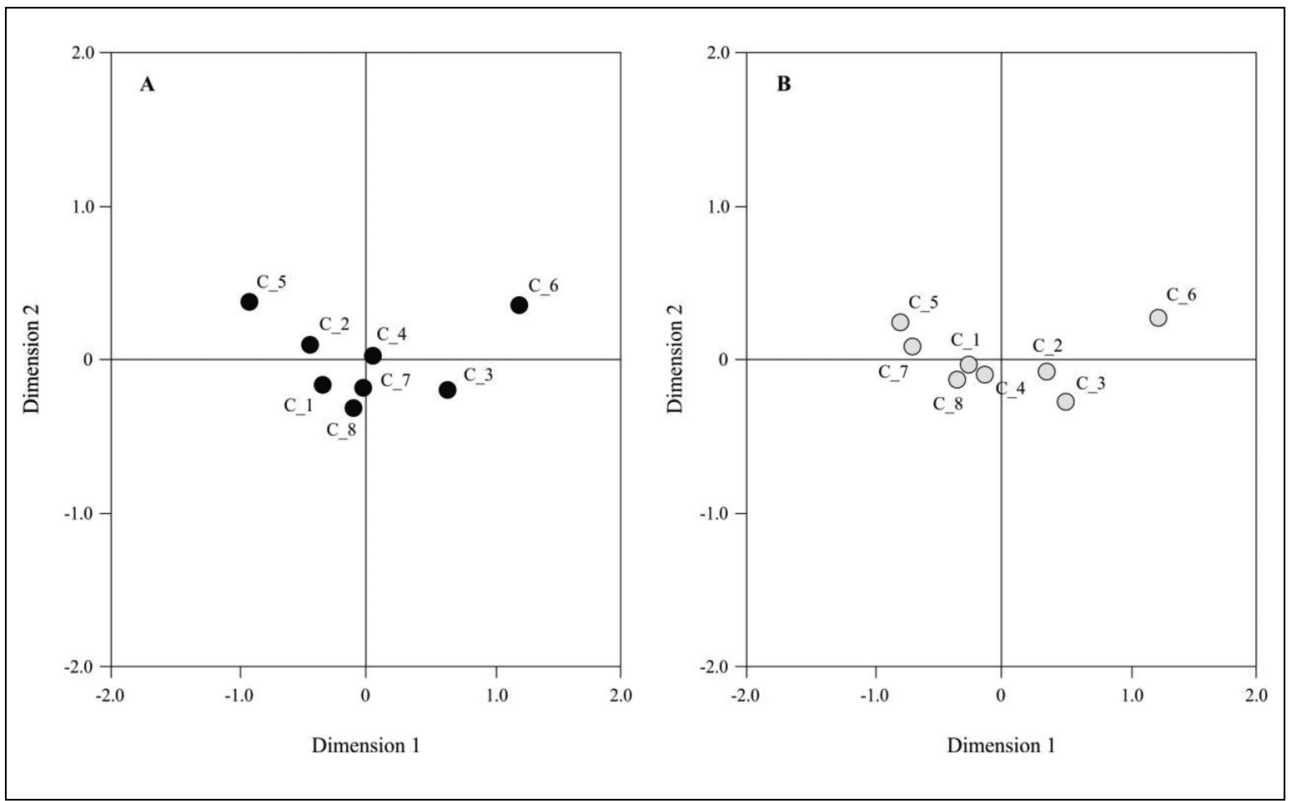

Source: own

Note: Evaluation of shopping in Slovakia (A); evaluation of shopping in Austria (B). C_1 - price oriented; C_2 - picky; C_3 - loyal; C_4 - recreational; C_5 - "fridge-type"; C_6 - pragmatic; C_7 - apathetic; C_8 - uncategorized.

the picky (C_2) consumer integrate into their shopping process the largest differences in evaluating retail store offerings between SR and AT.

\section{Discussion}

Shopper-oriented marketing refers to "the planning and execution of all marketing activities that influence a shopper along, and beyond, the entire path-to-purchase, from the point at which the motivation to shop first emerges through to purchase, consumption, repurchase, and recommendation" (Gicquel \& Castéran, 2016; Shankar et al., 2011). Although many studies have investigated the effect of perceived shopping value on both overall satisfaction and behavioural intention, comprehensive studies examining the additional role of shopping attributes in generating shopping value and behavioural intention are still scarce. There is a need to investigate this field, because in the process of shopping, consumers are assumed to form perceptions about different shopping attributes that may individually and significantly affect the overall value of shopping trip (Yeung et al., 2012; Albayrak et al., 2016). This means that consumption overreaches its economic function. The main indicator of consumer shopping behaviour abroad is the search for value, which manifests itself in consumer satisfaction.

As Križan et al. (2017) state, the crossborder shopping behaviour of Slovak consumers has changed in time and space. After 1990, in general, shopping was the most frequent reason of crossing the border (Baláž \& Williams, 2005). At the same time, it is possible to note that buying preferences of Slovak consumers have been different among target states. In the case of the Czech Republic and Hungary, shopping of food prevailed, while alcohol and cigarettes were typical for shopping in Ukraine. The Slovak consumers purchased mainly electronics in Austrian retail, whereas 
they shopped for shoes and clothes in the border region of Poland (Williams et al., 2001). As Baláž (2006) points out, the cross-border shopping between neighbouring states with similar levels of development (Hungary, Poland, the Czech Republic, Slovakia) was mainly caused by price differences of particular commodities, while the various offer of commodities was more important for shopping between states with different levels of development (Slovakia and Austria, Slovakia and Ukraine). Nowadays, the Slovak consumers buy predominantly food and common consumer goods, as well as driving fuel with favourable prices. It is necessary to note that cross-border shopping has an asymmetric character (Dołzbłasz, 2015). For Slovak retail, a negative balance of cross-border shopping is typical (cf. Civáň \& Krogman, 2012; Sikos \& Kovács, 2008; Tömöri, 2010).

The preliminary survey represents the comparison of Slovak shopping behaviour according to the suggested classification. The consumers point out what they expect in order to be satisfied with shopping at Slovak retailers. The consumers also transfer their behavioural model to shopping abroad, i.e. Slovaks aim at the price to quality ratio of the offerings.

The expectations from given offerings makes the consumers the judges of the success or failure of the store but also of the whole distribution channel. This means that the success or failure depends on how the distributer can grasp the character of the business. Since consumers are highly diversified, the emphasis lies on segmentation when evaluating offerings. Therefore, choosing the target customer is the basis of the distribution channel creation for the manufacturer as well as for the distributor. Moreover, the consumer influences the relationships between distributers and manufactures in various ways. From this perspective, the distributor and manufacturer need to get close to the consumer to react quicker to changing consumer needs. Thus, retail marketers and shopping centres can use information from this study to develop campaigns that target the benefits sought by cross-border and other international shoppers. The economic benefits of shopping in Austria or other countries are important to visitors who go there to shop, as well as the communities that benefit from their expenditures (Sullivan et al., 2012).

\section{Conclusions}

Cross-border shopping is a phenomenon of increasing importance in the context of consumer attraction by foreign countries. Recognizing changes in cross-border travel tendencies is crucial for retailers to do business effectively (Anderson \& van Wincoop, 2004). This could also help national and local governments to proactively manage border crossings, decrease financial losses, and support economic development along the border, etc. (Sener et al., 2015; Asplund et al., 2007; Michalkó et al., 2014). Shopping across a national border shows some specific triggers and barriers (Bygvrå, 2019).

In the case of Slovak residents shopping in Austria, the main reason is not price but product quality and the resulting wide variety of day-to-day products. This leads the consumer to positively evaluate shopping in Austria but also to change their shopping behaviour, thus creating new consumer types that would not otherwise exist in Slovak conditions. Moreover, Slovak consumers have observed differences between products sold under the same brand in Slovakia and Austria. The problem of different quality of the same products of the same brand was discussed at the level of the European Union. This is reflected in the resulting sensory attributes of the final products which consumers consequently evaluate from a quality and price perspective. Since this area has not seen much research, this marks the beginning of studying consumer behaviour in the context of cross-border shopping in Slovakia. Therefore, we can expect that Slovak consumers expect more added value from shopping in Austria which leads to more critical perceptions. An economical aspect has to be taken into account since Bratislava became the fourth most economically performing region in the European Union and in the context of long-term consumer saturation with stable retail offerings, consumers want assortment change. Thus, we can conclude that the Slovak grocery market is not responding to consumers who are willing to pay more, i.e. expect to buy products with more added value, not only from a quality and price perspective. Cross-border shopping, besides an economical dimension, also has a social one. The retail chains in Austria, which are located near the border with Slovakia, try to get closer to Slovak customers by employing Slovak-speaking personnel. This is the way 
new formal and informal interpersonal relations arise, which were interrupted during the communist regime.

Acknowledgement: This work was supported by the Slovak Research and Development Agency under contract No. APVV-16-0232, and by VEGA 1/0066/18 and VEGA 2/0113/19.

\section{References}

Albayrak, T., Caber, M., \& Çömen, N. (2016). Tourist shopping: The relationships among shopping attributes, shopping value, and behavioral intention. Tourism Management Perspectives, 18, 98-106. https://doi. org/10.1016/j.tmp.2016.01.007

Akerlof, G. A., \& Kranton, R. E. (2000). Economics and Identity. The Quarterly Journal of Economics, 115(3), 715-753. https://doi. org/10.1162/003355300554881

Anderson, J. E., \& van Wincoop, E. (2004). Trade costs. Journal of Economic Literature, 42(3), 691-751. https://doi. org/10.1257/0022051042177649

Ardelet, C., Slavich, B., \& de Kerviler, G. (2015). Self-referencing narratives to predict consumers' preferences in the luxury industry: A longitudinal study. Journal of Business Research, 68(9), 2037-2044. https://doi. org/10.1016/j.jbusres.2015.02.017

Asplund, M., Friberg, R., \& Wilander, F. (2007). Demand and distance: Evidence on cross-border shopping. Journal of Public Economics, 91(1-2), 141-157. https://doi. org/10.1016/j.jpubeco.2006.05.006

Baláž, V. (2006). Slovakia: EU Accession and Cross-Border Travel. In D. Hall, M. Smith \& B. Marciszewska (Eds.), Tourism in the New Europe: The Challenges and Opportunities of EU Enlargement (pp. 92-103). Wallingford: CABI. https://doi.org/10.1079/9781845931179.0092

Baláž, V., \& Williams, A. M. (2005). International tourism as bricolage: an analysis of Central Europe on the brink of European Union membership. International Journal of Tourism Research, 7(2), 79-93. https://doi. org/10.1002/jtr.514

Balogh, P., \& Pete, M. (2018). Bridging the gap: cross-border integration in the SlovakHungarian borderland around ŠtúrovoEsztergom. Journal of Borderlands Studies, 33(4), 605-622. https://doi.org/10.1080/08865 655.2017 .1294495
Bar-Kolelis, D., \& Dopierala, L. (2014). Ukrainian cross-border shoppers influence at the Polish and Romanian borders. A comparative study from Suceava and Lublin. Romanian Review on Political Geography/ Revista Româna Geografie Politica, 16(2), 78-87.

Bellenger, D. N., Robertson, D. H., \& Greenberg, B. A. (1977). Shopping center patronage motives. Journal of Retailing, 53(2), 29-38.

Binsztok, A. (2011). Kiedy krola drąży skałę, czyli droga do mistrzostwa w komunikacji perswazyjnej. Gliwice: Helion.

Bock, T., \& Uncles, M. (2002). A taxonomy of differences between consumers for market segmentation. International Journal of Research in Marketing, 19(3), 215-224. https://doi.org/10.1016/S0167-8116(02)00081-2

Borg, I., \& Groenen, P. (2003). Modern Multidimensional Scaling Theory and Applications. Journal of Educational Measurement, 40(3), 277-280. https://doi. org/10.1111/j.1745-3984.2003.tb01108.x

Bygvrå, S. (1998). The road to the single European market as seen through the Danish retail trade: Cross-border shopping between Denmark and Germany. International Review of Retail, Distribution and Consumer Research, 8(2), 147-164. https://doi. org/10.1080/09593969800000003

Bygvrå, S. (2009). Distance and cross-border shopping for alcohol: - evidence from Danes' cross-border shopping 1986-2003. Nordic Studies on Alcohol and Drugs, 26(2), 141-163. https://doi.org/10.1177/145507250902600203

Bygvrå, S. (2019). Cross-border shopping: Just like domestic shopping? A comparative study. GeoJournal, 84(2), 497-518. https://doi. org/10.1007/s10708-018-9871-6

Choi, M., Law, R., \& Heo, C. Y. (2016). Shopping destinations and trust - Tourist attitudes: Scale development and validation. Tourism Management, 54, 490-501. https://doi. org/10.1016/j.tourman.2016.01.005

Choi, M., Law, R., \& Heo, C. Y. (2018). An Investigation of the Perceived Value of Shopping Tourism. Journal of travel Research, 57(7), 962-980. https://doi. org/10.1177/0047287517726170

Civáň, M., \& Krogmann, A. (2012). Nákupný turizmus medzi Slovenskom a Rakúskom. Geografické informácie, 16(1), 42-50. https://doi.org/10.17846/GI.2012.16.1.42-50 
Di Matteo, L., \& Di Matteo, R. (1996). An analysis of Canadian cross-border travel. Annals of Tourism Research, 23(1), 103-122. https://doi.org/10.1016/0160-7383(95)00038-0

Dołzbłasz, S. (2015). Symmetry or asymmetry? Cross-border openness of service providers in Polish-Czech and Polish-German border towns. Moravian Geographical Reports, 23(1), 2-12. https://doi.org/10.1515/mgr-2015-0001

Doong, H.-S., Wang, H.-C., \& Law, R. (2012). An Examination of the Determinants of In-Flight Duty-Free Shopping: Hedonic and Utilitarian Motivations. International Journal Of Tourism Research, 14(3), 303-306. https://doi. org/10.1002/jtr.1870

Drtina, T. (1995). The Internationalisation of Retailing in the Czech and Slovak Republics. Service Industries Journal, 15(4), 191-203. https://doi.org/10.1080/02642069500000057

Gicquel, I., \& Castéran, H. (2016). Linking usage and shopping: How value experiences can distinguish consumers. Journal of Retailing and Consumer Services, 30, 165-174. https://doi.org/10.1016/j.jretconser.2016.01.014

Hogan, K. (2010). Psychologiaperswazji. Warszawa: Czarna Owca.

Jung, K., \& Takane, Y. (2015). Multidimensional Scaling I. In International Encyclopedia of the Social \& Behavioral Sciences (Second Edition) (pp. 34-39). Amsterdam: Elsevier. https://doi. org/10.1016/B978-0-08-097086-8.42045-3

Kita, J. et al. (2016). Marketing. Bratislava: lura Edition.

Kita, P., \& Grossmanová, M. (2014). Reflection of Bratislava Retail Network Selected Aspects of Consumer Behaviour. Business: Theory and Practice, 15(3), 279-284. https://doi.org/10.3846/btp.2014.28

Kohijoki, A. M., \& Marjanen, H. (2013). The effect of age on shopping orientation-choice orientation types of the ageing shoppers. Journal of Retailing and Consumer Services, 20(2), 165-172. https:/doi.org/10.1016/j. jretconser.2012.11.004

Krásný, T. (1992). Retailing in Czechoslovakia. International Journal of Retail and Distribution Management, 20(6), 30-33. https://doi.org/10.1108/EUM0000000002966

Križan, F., Bilková, K., Kita, P., \& Siviček, T. (2016). Transformation of Retailing in Post-Communist Slovakia in the Context of Globalization. E\&M Economics and Management, 19(1), 148-164. https://doi. org/10.15240/tul/001/2016-1-011
Križan, F., Zeman, M., Bilková, K., Kita, P., \& Barlík, P. (2017). Cezhraničné nákupné správanie spotrebitel'ov zo Slovenska: prípadová štúdia z Hainburg an der Donau (Rakúsko). Geographia Cassoviensis, 11(2), 124-136.

Kunc, J., \& Križan, F. (2018). Changing European retail landscapes: New trends and challenges. Moravian Geographical Reports, 26(3), 150-159. https://doi.org/10.2478/mgr2018-0012

Lumpkin, J. R. (1984). The effect of retirement versus age on the shopping orientation of the older consumer. The Gerontologist, 24(6), 622-627. https://doi.org/10.1093/geront/24.6.622

Marcussen, C. (2014). Multidimensional scaling in tourism literature. Tourism Management Perspectives, 12, 31-40. https://doi.org/10.1016/j.tmp.2014.07.003

Mark, T., Niraj, R., \& Dawar, N. (2012). Uncovering Customer Profitability Segments for Business Customers. Journal Of BusinessTo-Business Marketing, 19(1), 1-32. https://doi. org/10.1080/1051712X.2011.593022

Maryáš, J., Kunc, J., Tonev, P., \& Szczyrba, Z. (2014). Shopping and Services Related Travel in the Hinterland of Brno: Changes from the Socialist Period to the Present/Spádovost za obchodem a službami v zázemí Brna: Srovnání období socialismu a současnosti. Moravian Geographical Reports, 22(3), 18-28. https://doi.org/10.2478/mgr-2014-0015

Mazanec, J. A. (1995). Positioning Analysis with Self-Organizing Maps. An Exploratory Study on Luxury Hotels. Cornell Hospitality Quarterly, 36(6), 80-95. https:/doi. org/10.1177/001088049503600621

Mazanec, J. A. (2009) Unravelling Myths in Tourism Research. Tourism Recreation Research, 34(3), 319-323. https://doi.org/10.1 080/02508281.2009.11081606

Meloun, M., \& Militký, J. (2004). Statistická analýza experimentálních dat. Praha: Academia.

Michalkó, G., Rátz, T., Hinek, M., \& Tömöri, M. (2014). Shopping tourism in Hungary during the period of the economic crisis. Tourism Economics, 20(6), 1319-1336. https://doi. org/10.5367/te.2014.0387

Michalski, E. (2004). Marketing-podrecznik akademicki. Warszawa: PWN.

Murphy, L., Moscardo, G., Benckendorff, P., \& Pearce, P. (2011). Evaluating tourist satisfaction with the retail experience in a typical tourist shopping village. Journal of Retailing 
and Consumer Services, 18(4), 302-310. https://doi.org/10.1016/j.jretconser.2011.02.004

Nagengast, L., Linzmajer, M., Böttger, T., \& Rudolph, T. (2015). Emotional and Behavioral Consequences of Cross-Border Shopping. AMS World Marketing Congress. Cham: Springer. https://doi.org/10.1007/978-3-31929877-1_144

Pilarska, A. (2016). How do self-concept differentiation and self-concept clarity interrelate in predicting sense of personal identity? Personality and Individual Differences, 102, 8589. https://doi.org/10.1016/j.paid.2016.06.064

Powęska, H. (2008). Cross-border shopping in Poland in the early 21st century. Acta Scientiarum Polonorum, Oeconomia, 7(1), 111-122.

Reed, A., Forehand, M. R., Puntoni, S., \& Warlop, L. (2012). Identity-based consumer behaviour. International Journal of Research in Marketing, 29(4), 310-321. https://doi. org/10.2139/ssrn.2176665

Régi, T., Rátz, T., \& Michalkó, G. (2015). Anti-shopping tourism: a new concept in the field of consumption. Journal of Tourism and Cultural Change, 14(1), 62-79. https://doi.org/ 10.1080/14766825.2015.1015542

Sener, I. N., Lorenzini, K. M., \& Aldrete, R. M. (2015). A synthesis on cross-border travel: Focus on El Paso, Texas, retail sales, and pedestrian travel. Research in Transportation Business \& Management, 16, 102-111. https:// doi.org/10.1016/j.rtbm.2015.05.002

Sharma, P., Chen, I. S., \& Luk, S. T. (2015). Tourist Shoppers' Evaluation of Retail Service A Study of Cross-Border Versus International Outshoppers. Journal of Hospitality \& Tourism Research, 42(3), 392-419. https://doi. org/10.1177/1096348015584439

Sikos, T. T., \& Kovács, A. (2008). Újtrendek a határ menti kiskereskedelemben DélnyugatSzlovákiában. Területi Statisztika, 11(6), 724-733.

Sirakaya-Turk, E., Ekinci, Y., \& Martin, D. (2015). The efficacy of shopping value in predicting destination loyalty. Journal of Business Research, 68(9), 1878-1885. https:// doi.org/10.1016/j.jbusres.2015.01.016

Spierings, B., \& van der Velde, M. (2008). Shopping, borders and unfamiliarity: Consumer mobility in Europe. Tijdschrift vooreconomischeen sociale geografie, 99(4), 497-505. https://doi. org/10.1111/j.1467-9663.2008.00484.x

Spilková, J. (2018). "Tell me where you shop, and I will tell you who you are": Czech shopper profiles according to traditional, largescale and alternative retail options. Moravian
Geographical Reports, 26(3), 186-198. https:// doi.org/10.2478/mgr-2018-0015

Stone, G. P. (1954). City shoppers and urban identification: observations on the social psychology of city life. American Journal of Sociology, 60(1), 36-45. https://doi. org/10.1086/221483

Sullivan, P., Bonn, M. A., Bhardwaj, V., \& DuPont, A. (2012). Mexican national cross-border shopping: Exploration of retail tourism. Journal of Retailing and Consumer Services, 19(6), 596-604. https://doi.org/10.1016/j.jretconser.2012.07.005

Szytniewski, B. B., Spierings, B., \& van der Velde, M. (2017). Socio-cultural proximity, daily life and shopping tourism in the Dutch-German border region. Tourism Geographies, 19(1), 63-77. https://doi.org/10.1080/14616688.2016 .1233289

Thomson, D. M. H., \& Crocker, C. (2013). A data-driven classification of feelings. Food Quality and Preference, 27(2), 137-152. https:// doi.org/10.1016/j.foodqual.2012.09.002

Timothy, D. J., \& Butler, R. W. (1995). Crossborder shopping: A North American perspective. Annals of tourism research, 22(1), 16-34. https://doi.org/10.1016/0160-7383(94)00052-T

Tömöri, M. (2010). Investigating shopping tourism along the borders of Hungary a theoretical perspective. GeoJournal of Tourism and Geosites, 6(2), 202-210.

Wilkinson, L. (1998). Multidimensional scaling. Systat 8.0: Statistics. 615-642.

Williams, A. M., Baláž, V., \& Bodnarová, B. (2001) Border regions and trans-border mobility: Slovakia in economic transition. Regional Studies, 35(9), 831-846. https://doi. org/10.1080/00343400120090257

Yeung, R. M. W., \& Yee, W. M. S. (2012). A profile of the mainland Chinese cross-border shoppers: cluster and discriminant analysis. Tourism Management Perspectives, 4, 106112. https://doi.org/10.1016/j.tmp.2012.06.001

Yuan, J., Fowler, D. C., Goh, B. K., \& Lauderdale, M. K. (2013). Mexican crossborder shoppers' motivations to the USA. International Journal of Culture, Tourism and Hospitality Research, 7(4), 394-410. https:// doi.org/10.1108/IJCTHR-02-2013-0004

Zinser, B. A., \& Brunswick, G. J. (2014). Cross-Border Shopping: A Research Proposal For A Comparison Of Service Encounters Of Canadian Cross-Border Shoppers Versus Canadian Domestic In-Shoppers. The International Business \& Economics Research Journal, 13(5), 1077-1087. https://doi.org/10.19030/iber.v13i5.8773 